\section{CEMAL KURNAZ}

\section{Divan Şiirinde Beden Dili}

\author{
Body Language in Divan Poetry
}

\section{Ö Z E T}

Konuşurken, duygu ve düşüncelerimizi belirtmek veya desteklemek için adına kısaca beden dili denilen kafa, kol, el, parmak, yïz gibi organlarımızla bir takım hareketler, jestler, mimikler yaparız. Bunlarm önemli bir kısm milletlere özel hareketlerdir. Bu hareketler, milletin fertleri tarafından çocukluktan başlayarak, görerek taklit yoluyla öğrenilir. Türklerde de beden dili örnekleri yaygındır.

Divan şiirinde beden dili örneklerine rastlanır. Beden dili örneklerini yaygın şekilde kullanan şairlerin başında Necâtî Bey gelir. Onun yaninda Ahmet Paşa, Amrî, Zâtî gibi şairlerin şiirlerinde de örneklere rastlanır. Bunlarm bir kısmı o hareketi tarif ederken, bir kısmı da Türkçe ifadelerin çă̆rışımı içinde o hareketi hayal ettiren örneklerdir.

A N A H T A R K E L İ M E L E R

Beden dili, Divan şiiri, Necâtî Bey, Ahmet Paşa, Zâtî.
A B S T R A C T

We make number of movements, gestures, facial expressions while talking to express our thoughts and feelings, with so-called body language, such as head, arms, hands, fingers, face our organs. A significant portion of these nations are special exercises. These movements are specific movements for nations. These movements are learned by the members of the nation with seeing and through imitation, starting from childhood. Examples of body language is common in Turkish.

The body language examples are found in Divan poetry. Widespread use examples of body language is seenNecati Bey's poetry. In Ahmet Pasha, Amri, Zati's poems, exampled. They described a part of that movement, while a portion of the Turkish expression that enrich the connotation of that movement are examples of imagination.

K E Y W O R D S

Body language, Divan poetry, Necati Bey, Ahmet Pasha, Zati.

Duygu ve düşüncelerimizi belirtmek veya desteklemek için kafa, kol, el, parmak, yüz gibi organlarımızla bir takım hareketler, jestler, mimikler yaparız. Bunların tamamına beden dili denir. Beden dili kişilere özel olabileceği gibi, her toplumun benimsediği ve görerek öğrenilen anonim hareketler de olabilir.

Amerika'da yaşayan ve atalarının İnebahtı Savaşında (1571) İspanyol ve Portekizlilere esir düssen Osmanlı askerleri olduğu sanılan Meluncanların etnik kökenleriyle ilgili en ilginç kanıtlardan birinin bir beden dili özelliği olduğunu duyunca çok şaşırdım. Dillerini, dinlerini, kültürlerini

" Prof. Dr., Gazi Üniversitesi Eğitim Fakültesi Türk Dili ve Edebiyatı Öğretmenliği Bölümü, Ankara (cemal.kurnaz@gmail.com). 
büyük ölçüde unutmuş olan bu insanlar, hayır derken başlarını yukarıya kaldırarak "cık" diye ses çıkarırlarmış. Bizim Amerikan filmlerinin etkisiyle artık başımızı sağa sola salladığımız düşünülecek olursa, "cık"ın Amerika'da yüz yıllardır süren direnişi daha bir anlam kazanır.' (Bu konuda film yönetmenlerimize bir görev düşer mi acaba?)

Bunları düşünürken, acaba Divan şiirinde beden dilimize ait örnekler var midır diye sordum. "Hayatta ne varsa edebiyatta da vardır" diyerek kendimizi bağladığımıza göre herhalde olmalıydı. Ararken 15. yy. şairimiz Necâtî Bey'de çok sayıda örnekle karşılaştım. O halde bir dil konuşulduğundan ve yazıldığından daha fazla bir şeydir; şiir de öyle. Onları okurken o dil sahiplerinin birtakım hareketler yaptığı, yapmasa bile o hareketleri zihninde canlandırdığı bir gerçek. Acaba bir dili sonradan öğrenenler beden diline ait bu incelikleri de hakkıyla öğrenebilirler mi? Bu bir araştırma konusudur.

Eski kültürümüzde ağız dolusu kahkaha ile gülmek hoş karşılanmazdı. Hz. Peygamber'in de bunu onaylamadığı, kendisinin tebessüm ettiği bilinmektedir. Gülme eylemi bazen kontrol edilemez, insan makaraları koyuverir. Bu gibi hallerde ağzı elle veya kolla kapamak bize özgü bir beden hareketi idi. Necâtî bir beytinde gonca ile gülü karşılaştırır. Gonca henüz açılmamış, belki ucundan birazcık açılmaya yüz tutmuş haldedir. Gül ise açılma işlemini sonuna kadar tamamlamış, bütün güzelliği ortaya çıkmıştır. Kişileştirme yoluyla gül ve goncanın nezaketinin karşılaştırıldığ1 beyitte, şair tercihini goncadan yana kullanır. Gül, çemende nezaket konusunda her ne kadar kendini beğenirse de gonca naz ile gülecek olsa elbisesinin koluyla ağzını kapatır. Gül, güzel olmakla birlikte kahkahayla gülen, bütün güzelliği ortada, kendini sakınmayan, edepten yoksun bir güzel olarak tasavvur edilmiştir. Gonca ise, gülerken ağzını kapatan kibar, görgülü bir genç kız olarak gülden üstündür. Buradaki beden hareketi bir refleks gibidir; gülme krizine giren kişi elbisesi-

\footnotetext{
${ }^{1}$ Meluncanlar hk. bk. http:/ /insanveevren.wordpress.com/2011/04/30/meluncanlar -kimdir/Erişim tarihi: 30 Nisan 2011; http:/ / www.turkavenue.com/teknoloji/yenigirisimler/582-anadoludan-apalacyaya-osmanli-levendleri.html Erişim tarihi: 28 Kasim 2009.
} 
nin yeniyle ağzını kapatır. Bu hareketin Türklerde en azından 15. yy.dan beri bilindiği anlaşılmaktadır:

Güller çemende kendilerin nâzenin tutar

Nâz ile gülse ağzına gonca yenin tutar(Necâtî1992: G 165/1)

Türkler her türlü nimeti saygıdeğer bulurlar. Suyu aziz bilirler. Yerde bir ekmek parçası bulsalar alıp öperler, başlarının üstüne koyarlar. Necâtî, rintlerin şaraba da nimet muamelesi yaparak ihtiram ettiklerini, ayakta içmekten edep edip, çömelerek içtiklerini söyler. Beyitte görüleceği üzere, şairin amacı bu beden hareketini anlatmak değildir. Asıl anlatmak istediği, sevgilinin zülfünün ârifane şekilde eğilerek dudaklarını öpmesidir. Burada sevgilinin portresi söz konusudur. Zülüfleri kıvrılarak dudaklarına değmiştir. Şair, kıvrık zülüfleri çömelmiş ârif bir rinde, dudakları da şaraba benzetmiştir:

Zülfün ki ârifâne eğilüp öper lebün

Bir rinddür ki câm-1 şarâbı çöker çeker(Necâtî1992: G 145/5)

Sevinçli bir haber alınca başlığını havaya fırlatmak bize özgü bir beden hareketidir. Demek ki askerden terhis olunca veya okuldan mezun olunca kepini havaya fırlatmanın tarihi oldukça eskidir. Bununla ilgili ilk hatıram çocukluk yıllarına uzanır. 1967 yılında, ilkokul sonrasında Antalya Aksu Öğretmen Okulu yatılı sınavlarına girmiştik. Anne-babalar, çocuklar bahçede heyecanla sonuçların açılanmasını bekliyorduk. Derken kazananların isimleri hoparlörden okunmaya başladı. O yıllarda öğretmen okulunda okumak çok önemli bir şeydi. Bu, mahrumiyet içindeki köy çocukları için en kısa yoldan meslek sahibi olmak demekti. Üstelik itibarı da yüksekti. Bir öğretmen babası olmak herkese nasip olmuyordu. Komşu köyden, oğlunun öğretmen olmasını çok isteyen bir baba, kaçıncı defa girip de kazanamayan çocuğunun bu son şansında kazand1ğını öğrenince sevinçten kendini kaybetti; bir çığlık atarak fötr şapkasını havaya fırlattı; en az beş dakika döne döne oynadı. Sonra çocuğun elinden tuttu, yürüdü gitti...

Divan şairleri güneşi renk ve şekil yönünden külaha (başa giyilen başlığa) benzetirler. Âşık Çelebi, Revânî'den söz ederken, "Şevk ü şâdîden 
dül-bendin (sarığın) çıkarup hevâya revân-ı perrân eyledi" şeklinde bir ifadeye yer verir (2010/3: 1388). Necâtî, iki beytinde bu benzetmeden hareketle sevinçten külahını göğe fırlatma âdetine işaret eder. İlkinde, güneşi başında külahı olan bir kişiye benzetir ve ona şöyle seslenir: Eğer seni sevgilinin yüzüne benzetme lütfunda bulundularsa, başlı̆̆ını sevinçten göğe at.

Benzetdilerse çihre-i dildâra ey güneş

Şevk ile germ olup külehin âsumâna at (Necâtî1992: G 33/3)

Necâtî ikinci beytinde, gökte görüneni güneş sanmayın; Şehzade Abdullah'ı tahtında gören güneş her seher sevincinden külahını göğe atar şeklinde bir hüsn-i talile yer verir:

Her seher taht-1 saâdetde göricek tapunı

Sevinüp göğe atar mihr safâdan külehi (Necâtî1992: Tercibent 4/3)

Zâtî de benzer söyleyişi sürdürür:

Pâdişâh-1 mülk-i aşkam gün değildür görünen

Göğe atdum germ olup zerrîn külâhumdur benüm (Zâtî1970/II: G $872 / 2)$

Bir de bunun tersi olarak üzüntüden külahını yere vurmak söz konusudur. Ahmet Paşa, güneş 1şıklarının yere düşmesini veya güneşin batmasını şairane bir sebep (hüsn-i talil) ile yorumlar. Mihrin bir anlamı güneş ise diğeri de sevgidir. Gökyüzünün sevgiliye âşık bir kişi olarak tasavvur edildiği beyitte, sevgisinin şiddetinden külahını yere vurduğu belirtilir. İlk mısrada bir vücut hareketi daha vardır: Yakasını yırtmak. Sabah vakti, âşık şeklinde kişileştirilerek, sevgilinin aya benzeyen yanağının özlemiyle yakasını yırttığı söylenir. Sabahın yakasını yırtması, tan yerinin ağarmasıdır. Amrî'nin beytinde yakasını yırtmak yerine gömleğini parçalamaktan söz edilir. Daha çok yas törenlerinde görülen bu iki hareket de üzüntü, öfke veya aşırı duygu yoğunluğundan kaynaklanır:

Subh yırtar yakasın mâh-ı ruhun şevki ile Âsumân mihrin elinden yire urur külehi (Ahmet Paşa 1992:G 341/2) 
İrte kâdî olıcak Hazret-i Hak zulmünden

Külehi yire urup çâk ideyin pîreheni (Amrî1979: G 139/4)

Bir metni ezberlerken ritmik olarak başı aşağı yukarı sallamak yaygın bir beden hareketidir. Hatta buna gövdenin de hafif yollu eşlik etmesi söz konusudur. Şair, sevgilinin boyunu şimşir ağacına benzetmekle birlikte, ondan daha güzel olduğunu söyler. Bu durumu anlatmak için, şimşirin rüzgârda sallanmasını, sevgilinin boyunun özelliklerini ezberlemek için sürekli başını sallaması olarak yorumlar:

Başını durmayuban saldugı şimşâd-1 çemen

Gâlibâ kâmetinün vasfını eder ezber (Necâtî G 72/6)

Buraya kadar verdiğimiz örnekler, beyitlerde doğrudan söz konusu edilen, toplumda âdet haline gelmiş beden hareketleridir. Bir de beytin içinde ifade olarak yer alıp da bir beden hareketini çağrıştırarak okurken onu yapmamızı veya hayal etmemizi sağlayan örnekler vardır. Necâtî'nin şu beytinde olduğu gibi:

\section{Lâle-hadler yine gülşende neler itmediler}

Servi yürütmediler goncayı söyletmediler (Necâtî 1992: G 198/1)

"Lale yanaklı güzeller gül bahçesinde neler etmediler; serviyi yürütmediler, goncayı söyletmediler..."

2009 yılında, dünyanın bütün Türkoloji bölümlerinden öğrencilerin toplandığı bir sınıfa bu beyti okudum. Buradaki beden hareketini bilen var mi diye sordum. Arnavutluk'tan Rozeta ben biliyorum dedi. Türk asıllı mısın veya Türk arkadaşların mı var, dedim; hayır cevabını verdi. Göster bakalım dedim. "Neler etmediler" sözünü söylerken sağ avucunu açarak iki yana hareket ettirdi. Şaştım kaldım. Yaptığı hareket doğru idi.

Şair, zihnimizde bu hareketi canlandırarak, neler neler etmediler canım, o kadar çok ki saymakla bitmez; ben size veznin izin verdiği kadar, iki örnek vereyim, demek ister. Lale yanaklı güzeller gül bahçesinde bir sürü vukuat işlemişlerdir. Birincisi serviyi yürütmemişler. Servi yürür mü? Zaten sabittir. Belli ki burada bir kişileştirme söz konusudur. Lale 
yanaklı güzellerin boyları serviye benzer ama ondan daha üstündür. Servi/ler onların boylarının kendilerinden daha güzel olduğunu görünce yerlerinde kala kalmışlar, adım atmaya mecalleri olmamış. Gerçekliği şairane bir sebeple yorumlamaya biz hüsn-i talil diyoruz. Aynı şekilde goncalar da güzellerin kibar konuşmalarını işitince kendilerine benzeyen dudaklarının daha üstün olduklarını görmüşler ve ağılarını bıçak açmamış. Beyitteki yine kelimesi, hep olagelen bir olayın son tekrarını belirtir. Beytin anlam zenginliğini sağlayan ise, neler etmediler sözüne eşlik eden beden hareketidir.

Şehirli Türkçesinin inceliklerini, atasözü, deyim ve tabirlerini şiirlerinde bütün doğallığı ile kullanma başarısını gösteren Necâtî Bey, beden dilinin özelliklerine de yer verir. Bunların tamamını incelemek uzun zaman alır. "Neler" sözünün farklı bağlamlarda kullanımı bunlar arasında dikkati çeker:

Gözüm yaşın ayağından sen ırmağ istedin ammâ

Neler ider sana ey serv bu gözyaşı durudur (Necâtî1992: G 137/5)

Dünyâ yüzinde bundan ulu müşkil olmaya

Gerçi musîbet oldı cihânda neler neler(Necâtî1992: Terkibbent 2/7)

Ey Hatiboğlu Seyid Ahmedcik

Senin içün gör e neler dirler(Necâtî1992: Kit'a 35/1)

Nigâra gâh güneş gâh olur kamer dirler

Görün o bî-bedelin yüzüne neler dirler(Necâtî1992: G 190/1)

Revâ midur ki güneş yüzüne kamer diyeler

Geceyle seyre çıkarsan dahi neler diyeler(Necâtî1992: G 117/1)

Her dem ey kaşı kemân sînede peykânundan

Dil-i bî-çâre neler çektiğin Allah bilür (Necâtî1992: G 64/3)

Ruhlarında zülfün ucından neler çekdüm didüm

Didi bes gavgâlı olur Rûm'da elbetde uç (Necâtî1992: G 40/4)

Gâhi kemân-i mihmet ü gâhi hadeng-i âh

Meydân-1 gamda âşık-1 miskîn neler çeker(Necâtî1992: G 145/2) 
Doğruldıcak Necâtî'den ayruğa tîrüni

Allah bilür ki haste gönülden neler geçer(Necâtî1992: G 58/7)

Rozeta'ya, peki şu beyitteki beden hareketi nedir diye sordum:

Âdeti hûbların cevr ü cefâdur ammâ

Bana itdüklerini kimselere itmediler(Necâtî1992: G 198/3)

Ayağa kalktı, beyti okudu. "Bana ettiklerini kimselere etmediler" mısraını okurken sağ eliyle yakasını tutup silkeledi. "Aferin, sen Türkçeyi öğrenmişsin" dedim.

Burada söz konusu edilen örnekler Divan şiirinde beden dili kullanımına dikkat çekmeyi amaçlamaktadır. Yapılacak sistematik akademik çalışmalar konuyu daha ayrıntılı ve kapsamlı olarak ortaya koyacaktır. 


\section{Kaynaklar}

Ahmed Paşa (1992): Ahmet Paşa Divanı, Haz. Ali Nihat Tarlan, Akçağ Yayınevi, Ankara.

Amrî (1979): Divan, Haz. Mehmed Çavuşoğlu, İstanbul Üniversitesi Edebiyat Fakültesi Yayınları, İstanbul.

Âşık Çelebi (2010): Meşấ'irü'ş-şu'arâ, İnceleme-Metin, C. 3, Hazırlayan: Filiz Kılıç, İstanbul Araştırmaları Enstitüsü Yayını, İstanbul.

http:/ /insanveevren.wordpress.com/2011/04/30/meluncanlar-

kimdir/Erişm tarihi: 30 Nisan 2011

http://www.turkavenue.com/teknoloji/yeni-girisimler/582-anadoludanapalacyaya-osmanli-levendleri.html Erişim tarihi: 28 Kasım 2009

Necâtî (1992): Necâtî Bey Divanı, Haz. Ali Nihat Tarlan, Akçağ Yayınevi, Ankara.

Zâti (1970): Zâtî Divanı,C. II, Haz. Ali Nihat Tarlan, İstanbul Üniversitesi Edebiyat Fakültesi Yayınları, İstanbul. 